\title{
HEAT RELEASE RATE AS A PARAMETER FOR FIRE SPREAD - A CASE STUDY
}

UDC 614.84:519.872

\author{
Darko N. Zigar, Dušica J. Pešić, Milan Đ. Blagojević \\ University of Niš, Faculty of Occupational Safety in Niš, Serbia
}

\begin{abstract}
Indoor fires very often may cause great material damage and endanger human lives. The heat produced by fire affects the heating and ignition of surrounding flammable materials, as well as the heating of the building structure, causing its damage. It is well known that fire spread mostly depends on flammability and quantity of surrounding material, but small differences in the amount of fuel can significantly affect the speed of fire spread, and consequently, the rate of heat released by fire. In this paper, the influence of the heat release rate on fire spreading is shown. The Large Eddy Simulation method of the Fire Dynamics Simulator software package has been used to investigate the prediction of fire dynamics in a compartment. Numerical results show that the fire dynamics in the compartment is largely dependent on the quantity of fire load mass and the heat release rate during the fire.
\end{abstract}

Key words: compartment fire, heat release rate, incident heat flux, temperature, fire spread

\section{INTRODUCTION}

During a fire, released heat affects the further heating and ignition of flammable materials within the limited space, especially in the case of indoor fires, as well as the heating of the structural elements of the building structure, causing their damage [3].

Because of that, fire severity is defined as a measure of the destructive impact of a fire on structural elements or as a measure of the temperature reached during a fire. Factors influencing the intensity of indoor fires are: quantity, type, density and distribution of fire load mass, way of its combustion, amount of released heat, size and geometry of indoor space, ventilation conditions, etc. [7].

The amount of released heat depends on the type and amount of mass fire load, the amount of oxygen present in the room, as well as the phase of the fire [1]. The heat released during a fire is a basic parameter that drives all other physical and chemical processes that accompany a fire.

Received September 11, 2020 / Accepted October 12, 2020

Corresponding author: Dušica J. Pešić

University of Niš, Faculty of Occupational Safety in Niš, Serbia, Čarnojevića 10a, 18000 Niš, Serbia

E-mail: dusica.pesic@znrfak.ni.ac.rs 
As a consequence of the release of heat, a flame appears and combustion products are formed. The heat also affects the height and speed of flame propagation, ignition of the surrounding fire load mass and smoke dispersion. The released heat also affects the diffusion of air into the combustion zone and the flow of products. On the other hand, it also affects the movement of the product. Namely, due to the released heat, the density of the product decreases, the current products vertically upwards, driven by a strong buoyancy force due to the temperature difference between the fire product and the surrounding air.

For these reasons, the prediction of fire dynamics in a compartment is very important. In this paper, the influence of heat release rate on the fire spread is analyzed. Large Eddy Simulation method of Fire Dynamics Simulator software package has been used to investigate the fire parameters inside a building compartment.

\section{THEORETICAL BACKGROUND}

Fire is a process of uncontrolled combustion that is accompanied by endangering the health and lives of people, as well as significant material losses. The risk of fire to human life and health is based on the thermal effect (radiation) of the fire flame and the toxic effect of fire products.

There is a risk of the fire spreading if there is flammable material in the vicinity of the fire because the heat radiated by the fire flame can cause the ignition of the surrounding materials. Criteria for ignition of materials due to thermal radiation of flame are usually defined by "critical heat flux" which is defined as the lowest intensity of heat flux on the surface of the material that will cause its ignition or "critical surface temperature" which represents the lowest surface temperature of the material that will cause its ignition.

Table 1 Critical surface temperature of wood

\begin{tabular}{lc}
\hline Author & Critical heat flux $\left[\mathrm{kW} / \mathrm{m}^{2}\right]$ \\
\hline Ashton & 12 \\
Drysdale & 12 \\
Fangrat et al. & $10.1-12.1$ \\
Moghtaderi et al. & $10.3-14,00$ \\
Tran and White & $10.0-12.4$ \\
White and Dietenberger & $10-13$ \\
\hline
\end{tabular}

Table 2 Critical surface temperature of wood

\begin{tabular}{lc}
\hline Author & Critical temperature, $\left[{ }^{\circ} \mathrm{C}\right]$ \\
\hline Angell et al. & 204 \\
Fangrat et al. & $296-330$ \\
Graf & $236-321$ \\
Hill and Corney & $218-330$ \\
White and Dietenberger & $300-400$ \\
Yang et al. & $190-310$ \\
\hline
\end{tabular}

The experimentally obtained values of the critical heat flux and the temperature on the surface of the wood that causes its ignition in Table 1 and Table 2 are shown [2]. 


\section{NUMERICAL STUDY}

\subsection{Methodology}

Computational Fluid Dynamics (CFD) modeling is nowadays applied for studies of turbulent flows such as fire. The turbulence methods include Reynolds Averaged NavierStokes equation, Direct Numerical Simulation (DNS) and Large Eddy Simulation (LES) methods.

Fire Dynamics Simulator (FDS) as an open-source CFD software package is widely used for fire-related studies, because it is suitable for a wide range of thermally driven flow scenarios both outdoors and inside a built environment [8]. FDS solves numerically a form of the Navier-Stokes equations approximate for low-speed, thermally-driven fluid. The governing equations for a thermally expandable, multi-component mixture of ideal gases are, as follows [5]:

Conservation of mass:

$$
\frac{\partial \rho}{\partial t}+\nabla \cdot \rho \mathbf{u}=\dot{m}_{b}^{\prime \prime}
$$

Conservation of individual gaseous species:

$$
\frac{\partial}{\partial t}\left(\rho Y_{\alpha}\right)+\nabla \cdot \rho Y_{\alpha} \mathbf{u}=\nabla \cdot \rho D_{\alpha} \nabla Y_{\alpha}+\dot{m}_{\alpha}^{\prime \prime \prime}+\dot{m}_{b, \alpha}^{\prime \prime \prime}
$$

Conservation of momentum:

$$
\frac{\partial}{\partial t}(\rho \mathbf{u})+\nabla \cdot \rho \mathbf{u u}+\nabla p=\rho \mathbf{g}+\mathbf{f}_{b}+\nabla \cdot \tau_{i j}
$$

Conservation of energy which is written in terms of the sensible enthalpy:

$$
\frac{\partial}{\partial t}\left(\rho h_{s}\right)+\nabla \cdot \rho h_{s} \mathbf{u}=\frac{D p}{D t}+\dot{q}^{\prime \prime \prime}-\dot{q}_{b}^{\prime \prime}-\nabla \cdot \dot{q}^{\prime \prime}+\varepsilon
$$

where $\rho$ - density, $\mathbf{u}$ - velocity vector; $T$ - temperature; $D_{\alpha}$ - diffusion coefficient; $Y_{\alpha}$ mass fraction of $\alpha^{\text {th }}$ species; $\dot{m}_{\alpha}^{\prime \prime \prime}$ - mass production rate per unit volume of species $\alpha$ by chemical reactions; $\dot{m}_{b, \alpha}^{\prime \prime \prime}$ - production of species $\alpha$ by evaporating particles; $p$ - pressure; $\mathbf{g}$ - is gravity vector; $\mathbf{f}_{\mathrm{b}}$ - external force vector; $\tau_{i j}$ - viscous stress tensor; $h_{\mathrm{s}}$ - sensible enthalpy; $\dot{\mathbf{q}}^{\prime \prime}$ - heat flux vector; $\dot{q}^{\prime \prime}$ - heat release rate per unit volume from a chemical reaction; $\dot{q}_{b}^{\prime \prime \prime}$ - energy transferred to the evaporating droplets; $\dot{q}^{\prime \prime}$ - conductive and radiative heat fluxes; $\varepsilon$ - dissipation rate.

Energy transport (Eq. (4)) consists of convection, conduction and radiation. Convection of heat is accomplished via the solution of the basic conservation equations. Gains and losses of heat via conduction and radiation are represented by the divergence of the heat flux vector, $\nabla \cdot \dot{\mathbf{q}}$, in the energy equation. The equation associated with the radiative part, $\nabla \cdot \dot{\mathbf{q}}_{\mathbf{r}}^{\prime \prime}$ is the Radiative Transport Equation for an absorbing, emitting, and scattering medium, as follows

$$
\begin{aligned}
& \mathrm{s} \cdot \nabla I_{\lambda}(x, s)=-\left[k(x, \lambda)+\sigma_{s}(x, \lambda)\right] I_{\lambda}(x, s)+ \\
& +B(x, \lambda)+\frac{\sigma_{s}(x, \lambda)}{4 \pi} \int_{4 \pi} \Phi\left(s, s^{\prime}\right) I_{\lambda}\left(x, s^{\prime}\right) d s^{\prime}
\end{aligned}
$$


where: $I_{\lambda}(x, s)$ is radiation intensity at wavelength $\lambda, s$ is direction vector of the intensity, $k(x, \lambda)$ is local absorption coefficient, $\sigma_{\mathrm{s}}(x, \lambda)$ is scattering coefficient, $B(x, \lambda)$ is emission source term, describing how much heat is emitted by the local mixture of gas, soot and droplets/particles, $\Phi\left(s, s^{\prime}\right)$ is a scattering phase function that gives the scattered intensity from direction $s$ to $s$, i.e.

$$
\frac{\Phi\left(s, s^{\prime}\right) d s^{\prime}}{4 \pi} .
$$

\subsection{Model configuration}

A computational domain ( $14 \mathrm{~m}$ wide, $12.5 \mathrm{~m}$ long and $3 \mathrm{~m}$ high) was designed for CFD LES simulations. The boundaries of the domain were all set to be naturally opened in order to gases flow freely in and out of the simulation domain.

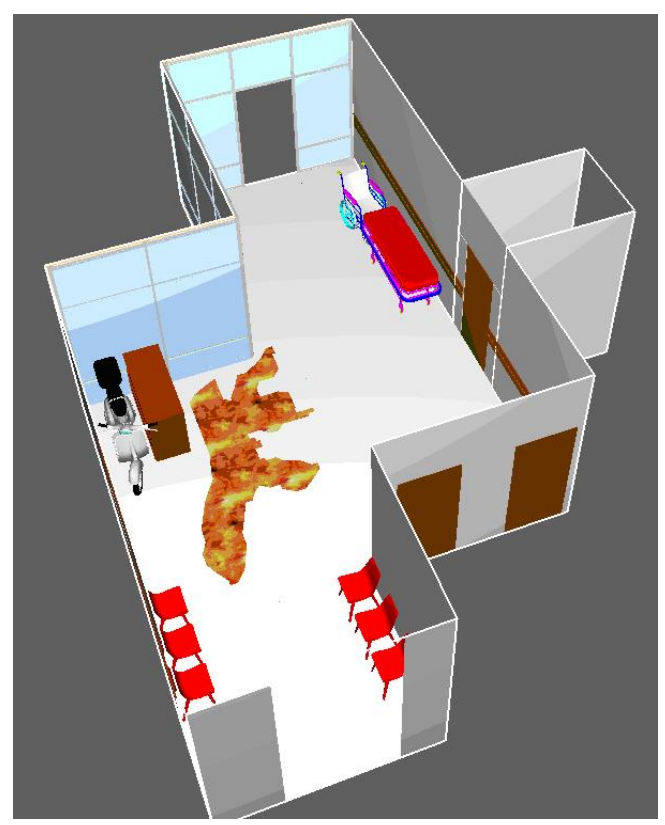

Fig. 1 Computational domain

For purpose of simulation described in this paper, inside the computational domain it is designed a part of the ambulance facility that fully corresponds to the real situation. The entrance door of the building is set as an aluminum-glass door, while the inner door in the building is made of wood. In the hall, there is a wheelchair and a bed for transporting patients with a metal construction with elements made of artificial leather, covered with a cotton sheet. Next to the counter for receiving patients, there is a counter made of wooden elements (plywood) measuring $1.2 \times 0.45 \times 0.9 \mathrm{~m}$. Behind the counter is a motorcycle type "Vespa", as well as two rows of benches of wooden metal construction in the hallway (Figure 1). 


\subsection{Fire parameters}

Fire load mass (flammable materials) of the building hallway consisted of wooden counter and chairs, wooden doors, cotton sheet. Fire load mass of motorcycle "Vespa" is a certain amount of gasoline in its tank. Properties of used materials are given in Table 3.

Table 3 Properties of flammable materials

\begin{tabular}{lcccc}
\hline Material & $\begin{array}{c}\text { Thickness } \\
{[\mathrm{m}]}\end{array}$ & $\begin{array}{c}\text { Density } \\
{[\mathrm{kg} / \mathrm{m} 3]}\end{array}$ & $\begin{array}{c}\text { Thermal conductivity } \\
{[\mathrm{W} / \mathrm{mK}]}\end{array}$ & $\begin{array}{c}\text { Ignition temperature } \\
{[\mathrm{C}]}\end{array}$ \\
\hline Wood & 0.2 & 750 & 0.14 & $240-310$ \\
Cotton & 0.003 & 40 & - & 280 \\
Gasoline & - & $0.75[\mathrm{~kg} / \mathrm{l}]$ & - & 232 \\
\hline
\end{tabular}

Pool fire (i.e. gasoline) in the hallway was set as a fire source. Reaction type of "OCTANE", according to the FDS reaction database [5] was specified for generating the fire source. The growth phase of the fire was specified by the t-square fire growth model [6]. Ultra fast fire was used for the simulations.

Simulations were carried out for the following cases of pool fire:

(1) Scenario 1: mass of gasoline was $0.7 \mathrm{l}$;

(2) Scenario 2: mass of gasoline was 1.01.

The duration of the numerical simulations was $60 \mathrm{~s}$.

\subsection{Numerical mesh}

For the LES applications, a relatively high mesh resolution is required because the numerical solution of the equations is better if the numerical grid is finer. However, the fine grid size needs a longer computing time. Therefore, it is important to determine an appropriate grid size that would optimize the solution accuracy and time. The grid cell size depends on the heat release rate (HRR) of the fire and the ambient air properties. These factors are combined to give a characteristic fire diameter $D^{*}$, as follows [5]

$$
D^{*}=\left(\frac{\dot{Q}}{\rho_{\infty} c_{p} T_{\infty} \sqrt{g}}\right)^{2 / 5}
$$

where: $\dot{Q}$ is HRR, $c_{p}$ is the specific heat of the smoke, $\rho_{\infty}$ is air density, $T_{\infty}$ is air temperature, and $g$ is acceleration due to gravity.

The grid size is determined by the non-dimensional expression $D^{*} / \delta \mathrm{x}$ where $\delta x$ is the nominal cell size. McGrattan et al. [4] suggest that the mesh size must be no larger than $0,1 D^{*}$ to obtain appropriate simulation results. For this investigation, the uniform grid of $0.05 \mathrm{~m}$ in the three spatial directions can be taken as a reasonable grid size. 


\section{RESULTS AND DISCUSSION}

\subsection{Heat release rate}

The simulation results of heat release rate of pool fire during combustion of 0.71 and 1.01 of gasoline are given in Figure 2.

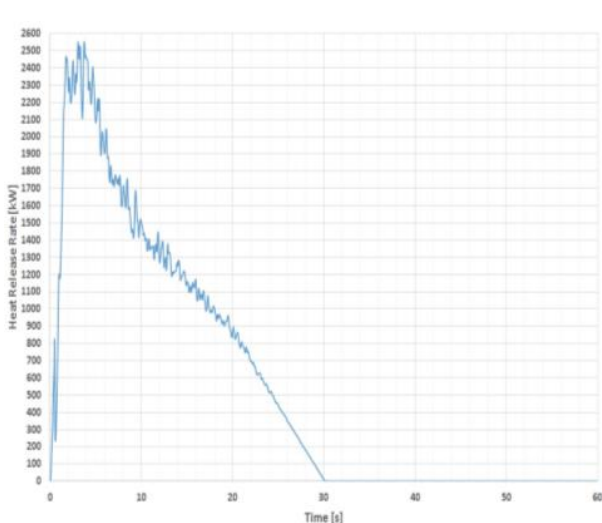

a)

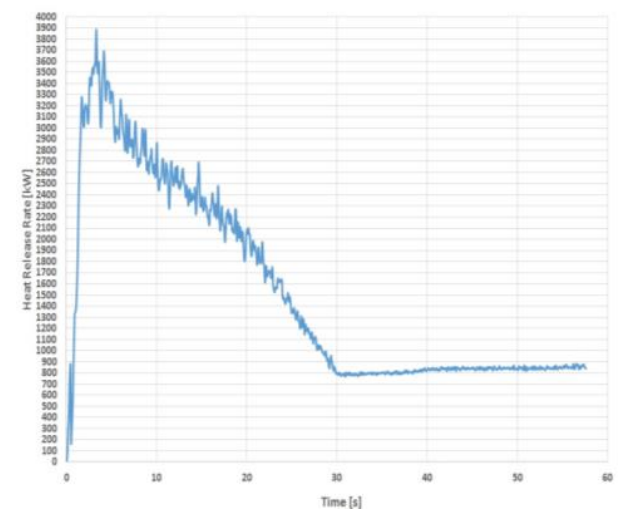

b)

Fig. 2 Heat release rate: a) scenario 1; b) scenario 2

As it can be seen in Figure 2, the maximum value of HRR for scenario 1 is $2.5 \mathrm{MW}$ and for scenario 2 is $3.9 \mathrm{MW}$.

\subsection{Fire dynamics}

The results of fire dynamics simulations for the corresponding scenario in Figures 3 and 4 and Tables 4 and 5 are shown.

Table 4 Fire dynamics of scenario 1

\begin{tabular}{lcl}
\hline Fig 3 & $\begin{array}{c}\text { Simulation } \\
\text { time }[\mathrm{s}]\end{array}$ & Fire dynamics \\
\hline a) & 2.5 & The height of the flame is $1.8 \mathrm{~m}$. \\
b) & 3.5 & The height of the flame is about $1 \mathrm{~m}$. \\
c) & 5.5 & The flame bends towards the wooden counter behind which is the "Vespa". \\
d) & 8.5 & A layer of smoke descended to half the height of the hallway. \\
e) & 20 & The whole hallway is filled with smoke. \\
f) & 30 & The fire was extinguished. \\
\hline
\end{tabular}




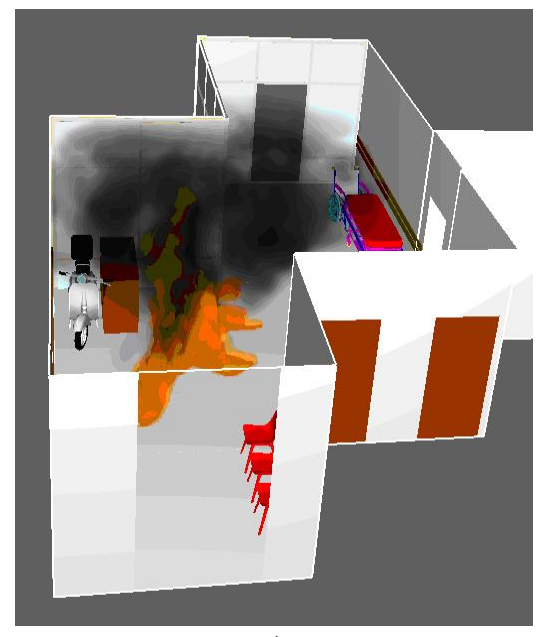

a)

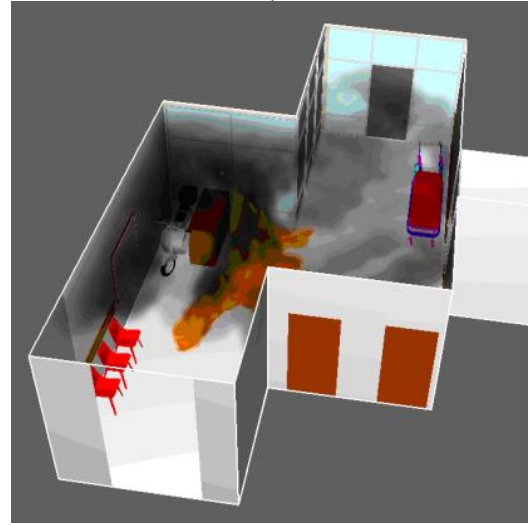

c)

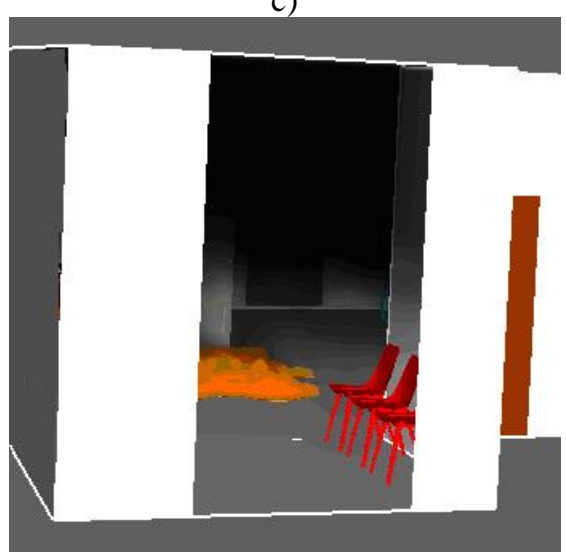

e)

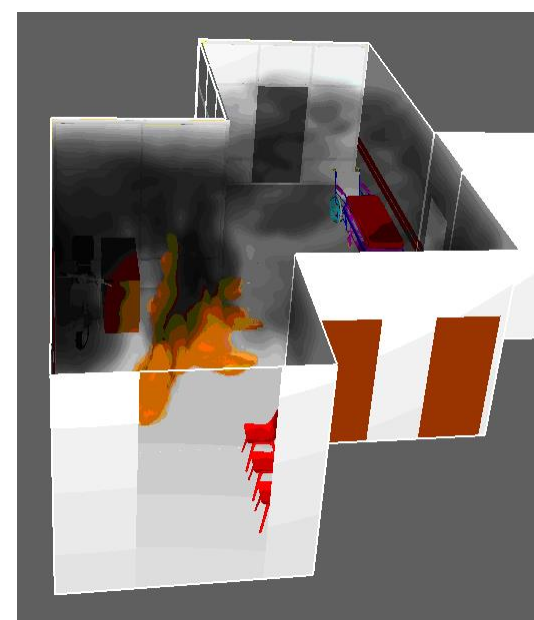

b)

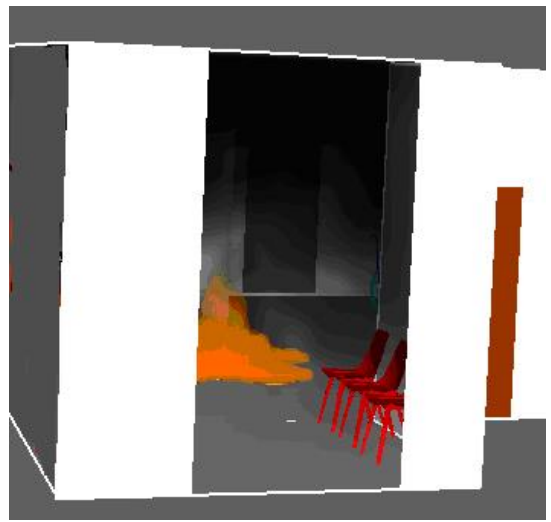

d)

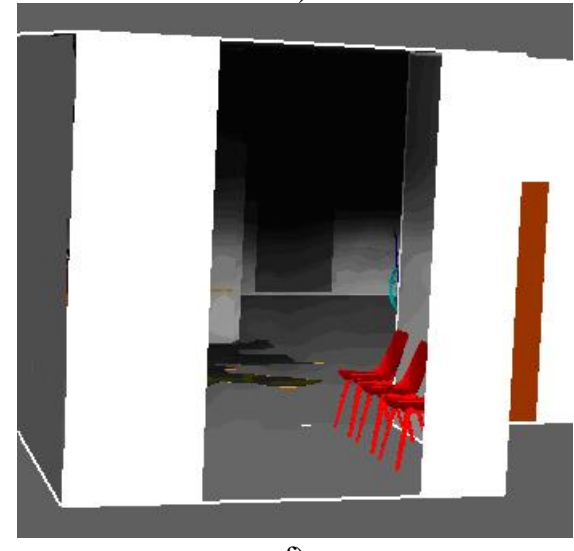

f)

Fig. 3 Fire dynamics for scenario 1 


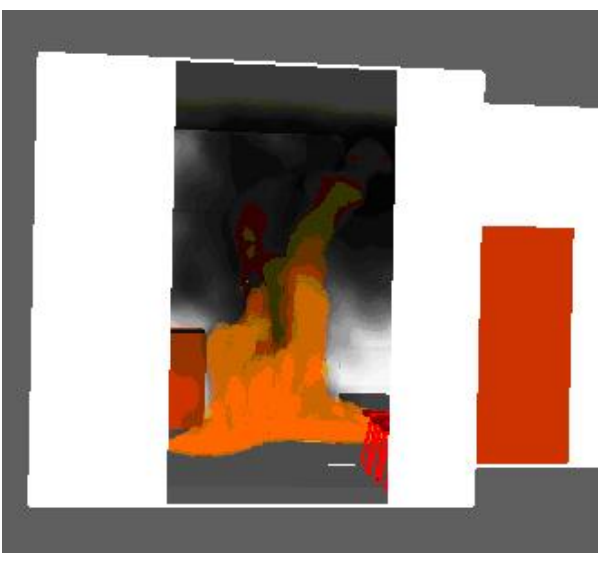

a)

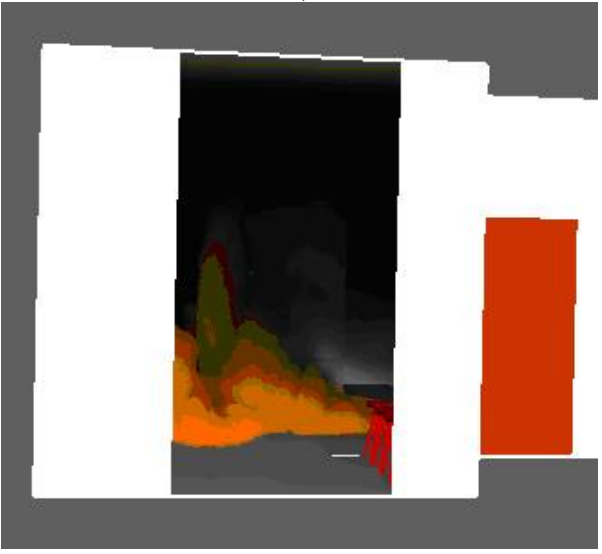

c)

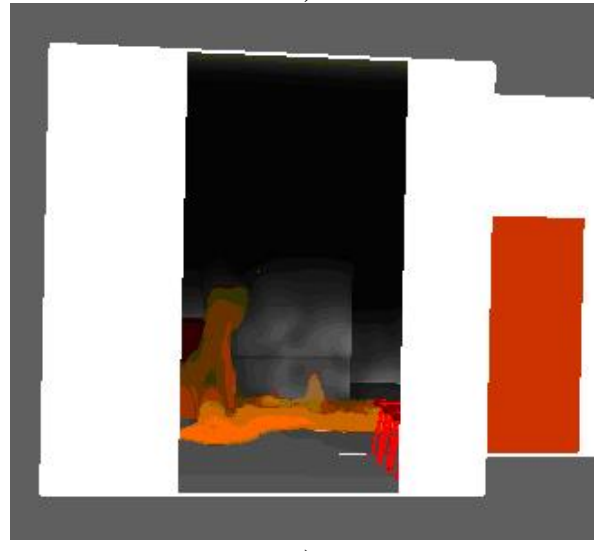

e)

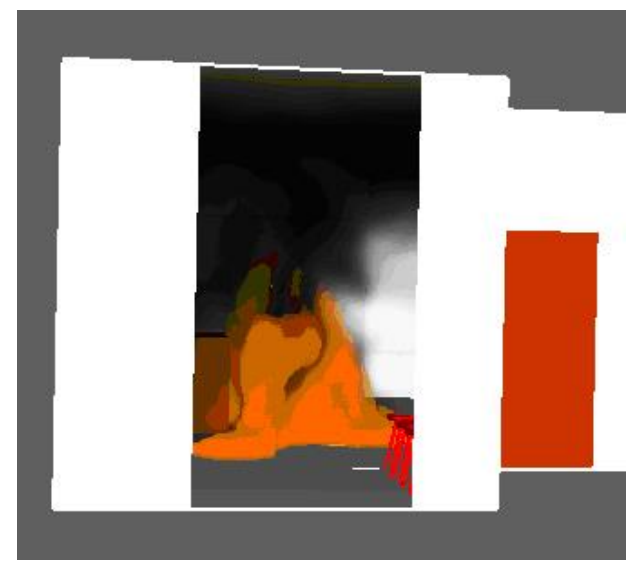

b)

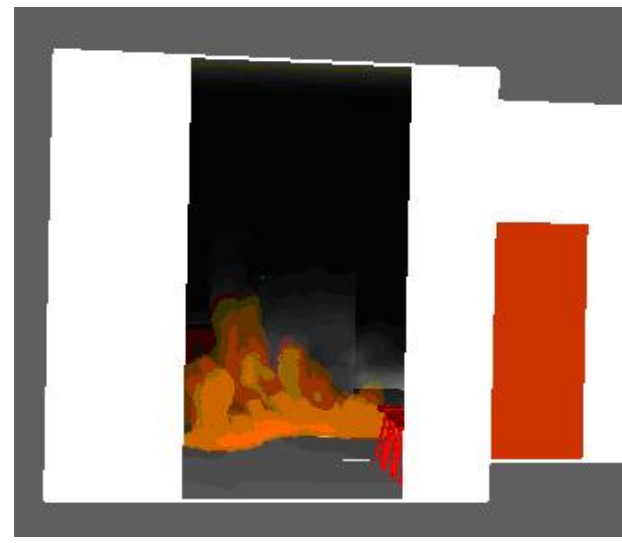

d)

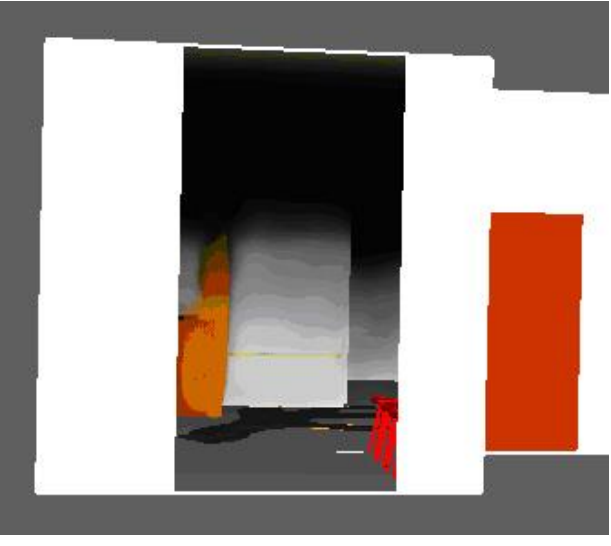

f)

Fig. 4 Fire dynamics for scenario 2 
Table 5 Fire dynamics of scenario 2

\begin{tabular}{ccl}
\hline Fig 4 & $\begin{array}{c}\text { Simulation time } \\
{[\mathrm{s}]}\end{array}$ & Fire dynamics \\
\hline a) & 2.2 & The height of the flame is $2.7 \mathrm{~m}$ \\
b) & 4.0 & The flame bends towards the wooden counter \\
c) & 7.5 & The fire captured a wooden counter \\
d) & 12.0 & Intensive combustion of gasoline spilled on the floor \\
e) & 25.0 & Calming fire on the floor \\
f) & 60.0 & The counter is still burning \\
\hline
\end{tabular}

\subsection{Heat flux on the surface of the counter exposed to flame radiation}

The intensity of the heat flux on the surface of the counter exposed to the fire flame for scenario 1 is shown in Figure 5.

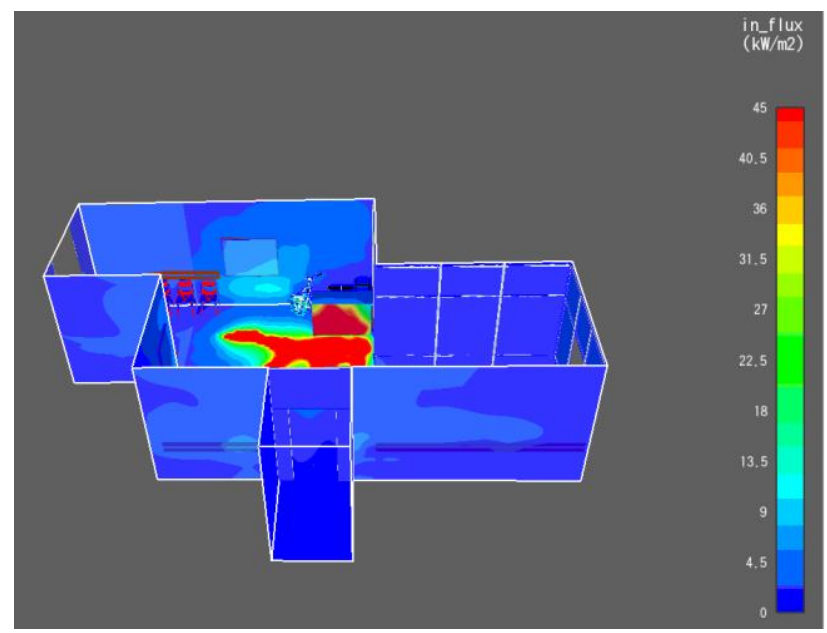

Fig. 5 Incidental heat flux on the surface of the counter for scenario 1

Scenario 1: As can be seen from Figure 5, during the fire in the period from $1.7 \mathrm{~s}$ to $17 \mathrm{~s}$, the value of the incident heat flux on the surface of the wooden counter is $45 \mathrm{~kW} / \mathrm{m}^{2}$. Based on the values given in Table 1, it can be concluded that the flux values are above the critical flux values at which the wood is ignited. Regardless of the fact that the value of the flux on the surface of the wood is high enough, the ignition did not occur because the fire was extinguished before the temperature of its ignition was reached.

The value of the heat flux on the surface of the counter immediately before its ignition (scenario 2) is shown in Figure 6.

Scenario 2: The value of the incident heat flux on the surface of the wooden counter immediately before its ignition is $60 \mathrm{~kW} / \mathrm{m}^{2}$, which is a higher value compared to the heat flux of $45 \mathrm{~kW} / \mathrm{m}^{2}$ that occurs on the counter surface in scenario 1 . Heat flux intensity of $60 \mathrm{~kW} / \mathrm{m}^{2}$ is enough to ignite the wooden counter for a very short period of time $(7.5 \mathrm{~s}$ from the beginning of the simulation). 


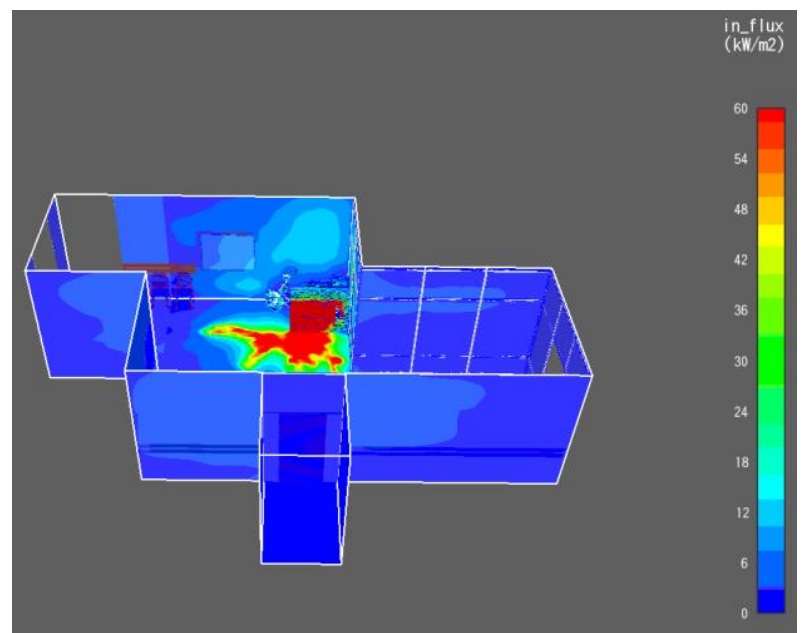

Fig. 6 Incidental heat flux on the surface of the counter for scenario 2

\subsection{Temperature fields on the counter surface exposed to the fire thermal effects}

The temperature fields on the surface of the counter exposed to the thermal effects of fire for scenarios 1 and 2 are shown in Figures 7 and 8.

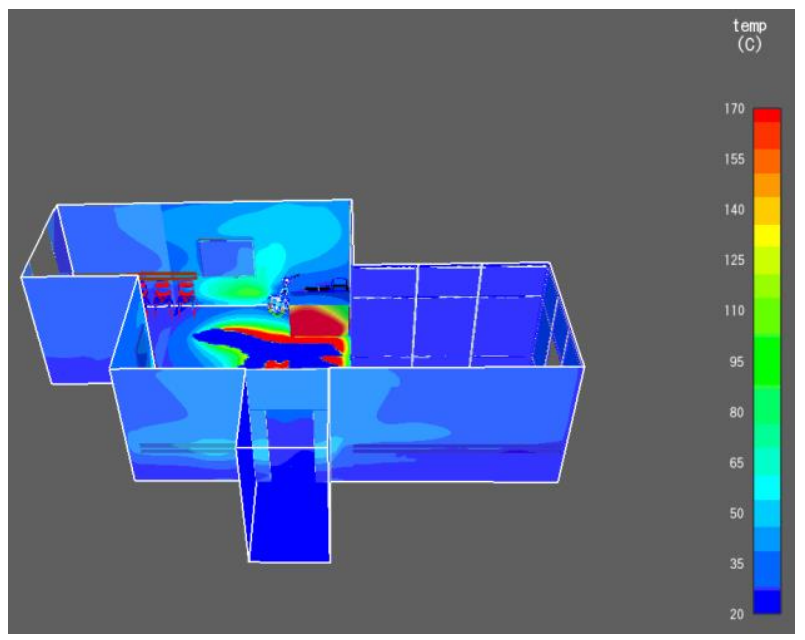

Fig. 7 Temperature on the surface of the counter for scenario 1 


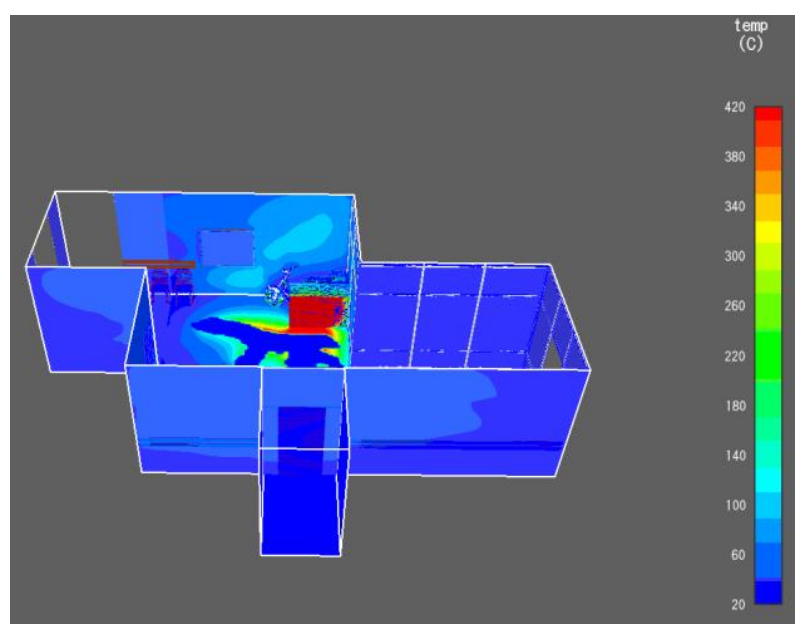

Fig. 8 Temperature on the surface of the counter for scenario 2

Scenario 1: During the simulation, in the period from $3 \mathrm{~s}$ to $50 \mathrm{~s}$, the value of the temperature on the surface of the wooden counter that is near the focus of the fire is 170 ${ }^{\circ} \mathrm{C}$. Based on the values given in Table 2 it can be concluded that the temperature values obtained by the simulation are below the temperature at which the wood is ignited. This conclusion is based on the fact, that regardless of the values of the incident flux that are sufficient to ignite the wooden counter, the duration of the fire of $30 \mathrm{~s}$ is insufficient to heat the wood to the ignition temperature.

Scenario 2: The simulation results show that the value of the temperature on the surface of the counter immediately before its ignition is $410{ }^{\circ} \mathrm{C}$. Due to the fact that the ignition temperatures of wood shown in Table 2 are in the range from $190{ }^{\circ} \mathrm{C}$ to $400{ }^{\circ} \mathrm{C}$ and that they are lower than the obtained value of the temperature on the surface of the counter, its ignition occurred due to the high flame temperature of about $850{ }^{\circ} \mathrm{C}$ during the combustion of gasoline on the floor of the hallway.

\section{CONCLUSIONS}

In the paper, FDS LES simulations were performed to study the fire dynamics and possibility of its spread inside a building compartment. The simulation results show as follow:

- In scenario 1 , during the combustion of 0.71 of gasoline, the highest achieved flame temperature in the center of the fire is about $400{ }^{\circ} \mathrm{C}$. The value of the incident heat flux on the surface of the wooden counter caused by the radiation of the fire flame is $45 \mathrm{~kW} / \mathrm{m}^{2}$. For a fire interval of $30 \mathrm{~s}$, the flame caused the rising of the counter temperature by $170{ }^{\circ} \mathrm{C}$, which is lower than the wood ignition temperature. There was no spread of fire in the compartment in this scenario.

- In scenario 2, during the combustion of 1.01 of gasoline, the flame temperature during the fire was high enough $\left(850^{\circ} \mathrm{C}\right)$ that it caused the wooden counter to ignite. In this scenario, there is a high probability of further spread of the fire because the fire from the wooden counter would most likely spread to the "Vespa" 
motorcycle parked behind the wooden counter. In that case, large-scale material damage would occur and the life of the persons present in the compartment would be endangered.

Acknowledgement. The paper is the result of research funded by the Ministry of Education, Science and Technological Development of the Republic of Serbia.

\section{REFERENCES}

1. Babrauskas, V. (2016) Heat Release Rates. In: SFPE Handbook of Fire Protection Engineering, (5th ed.), pp. 799-904

2. Bartlett, A.I, Hadden, R.M., Bisby, L:A. (2019) A Review of Factors Affecting the Burning Behaviour of Wood for Application to Tall Timber Construction, Fire Technology, Vol. 55, pp. 1-49.

3. Drysdale, D. (2011) An Introduction to Fire Dynamics (3rd ed.), Wiley, 474 p.

4. McGrattan, K.B., Baum, H.R., Rehm, R.G. (1998), Large eddy simulations of smoke movement, Fire Safety Journal, Vol. 30(1998), pp.161-178.

5. McGrattan, K., Hostikka, S., Floyd, J., Baum, H., Mell, R.R.W., McDermott, R. (2009), Fire Dynamics Simulator (Version 5.4) Technical reference guide. National Institute of Standards and Technology. Washington.

6. National Fire Protection Association, 2009. NFPA72 - National Fire Alarm and Signaling Code. Quincy.

7. Pešić, D.J., Raos T.M. (2017), Požari i građevinske konstrukcije, Univerzitet u Nišu, Fakultet zaštite na radu u Nišu, 219 str.

8. Pešić, D.J., Zigar, D.N., Raos T.M., Anghel, I. (2017), Simulation of Fire Spread between Residential Buildings Regarding Safe Separation Distance, Technical Gazette, Vol. 24, No. 4(2017), pp. 1137-1145.

\section{BRZINA OSLOBAĐANJA TOPLOTE KAO PARAMETAR KOJI UTIČE NA ŠIRENJE POŽARA - NUMERIČKA STUDIJA}

Požari u zatvorenom prostoru vrlo često mogu prouzrokovati veliku materijalnu štetu i ugroziti ljudske živote. Toplota oslobođena tokom požara utiče na zagrevanje i paljenje okolnih zapaljivih materijala, kao i na zagrevanje građevinske konstrukcije, prouzrokujući njeno oštećenje. Poznato je da širenje požara najviše zavisi od zapaljivosti i količine okolnog materijala. Male razlike u količini zapaljivog materijala mogu značajno uticati na brzinu širenja požara, a samim tim i na brzinu oslobađanja toplote tokom požara. U ovom radu prikazan je uticaj brzine oslobađanja toplote na širenje požara. Metoda simulacije velikih vrtloga softverskog paketa Fire Dinamics Simulator je korišćena za istraživanje predviđanja dinamike požara u zatvorenom prostoru. Numerički rezultati pokazuju da dinamika požara u velikoj meri zavisi od količine mase požarnog opterećenja i brzine oslobađanja toplote tokom požara.

Ključne reči: požar u zatvorenom prostoru, brzina oslobađanja toplote, kritični toplotni fluks, širenje požara 